\title{
Gambaran Mental Emosional pada Orang Tua yang Anaknya dirawat di Instalasi Gawat Darurat RSUP Prof. Dr. R. D. Kandou Manado
}

\author{
${ }^{1}$ I Dewa G. Adi Suputra \\ ${ }^{2}$ Theresia M. D. Kaunang \\ ${ }^{2}$ Herdy Munayang
}
${ }^{1}$ Program Studi Pendidikan Dokter Fakultas Kedokteran Universitas Sam Ratulangi Manado
${ }^{2}$ Bagian Psikiatri Fakultas Kedokteran Universitas Sam Ratulangi
Email: dewaadisuputra96@gmail.com

\begin{abstract}
Emotional mental disorder is a condition that indicates psychological changes in an individual. This disorder can manifest as symptoms of depression, psychosomatic disorders, and anxiety. Having a child hospitalized for a life-threatening illness or injury can cause deep psychological reactions to the parents. This study was aimed to determine the mental emotional profile among the parents whose children were treated at the Emergency Installation of Prof. Dr. R. D. Kandou Hospital from October to November 2017. This was a quantitative descriptive study with a cross sectional design. This study involved all parents whose children were treated in the emergency installation who met the inclusion criteria as many as 72 respondents. The instruments of the study were Self Reporting Questionnaire (SRQ) and Depression Anxiety Stress Scale (DASS). Univariate and bivariate analyzes were performed using SPSS. Based on SRQ and DASS questionnaire data filled by 72 respondents, 54 parents (75\%) had emotional mental disorders, consisting of 49 parents $(68.1 \%)$ suffering from anxiety from mild to very severe and 18 parents ( $25 \%)$ suffering from mild to very severe depression. The most dominant diseases of the children that caused anxiety to the parents were diarrhea, bronchopneumonia, and febrile seizures. Conclusion: The conditions of children treated in the Emergency Installation of Prof. Dr. R. D. Kandou Hospital could cause psychological stress in the form of anxiety and depression for the parents.
\end{abstract}

Keywords: emotional mental disorders, anxiety, depression, parents

\begin{abstract}
Abstrak: Gangguan mental emosional adalah kondisi yang mengindikasikan perubahan psikologik pada seseorang. Gangguan mental emosional dapat berupa gejala depresi, gangguan psikosomatik, dan kecemasan. Pengalaman memiliki anak yang dirawat di rumah sakit karena penyakit atau cedera yang mengancam jiwa dapat menyebabkan reaksi psikologik yang mendalam pada orang tua. Penelitian ini bertujuan untuk mengetahui gambaran mental emosional pada orang tua yang anaknya dirawat di IGD RSUP Prof. Dr. R. D. Kandou periode Oktober-November 2017. Jenis penelitian ialah deskriptif kuantitatif dengan studi potong lintang. Penelitian ini melibatkan semua orang tua yang anaknya dirawat di IGD dan memenuhi kriteria inklusi yaitu 72 responden orang tua. Instrumen yang digunakan ialah kuesioner Self Reporting Qustionnaire (SRQ) dan Depression Anxiety Stress Scale (DASS). Analisis univariat dan bivariat dilakukan dengan menggunakan SPSS. Berdasarkan perolehan data kuesioner SRQ dan DASS dari 72 responden, 54 orang tua (75\%) mengalami gangguan mental emosional, yang terdiri dari 49 orang tua $(68,1 \%)$ dengan kecemasan dari ringan hingga sangat berat dan 18 orang tua (25\%) dengan depresi ringan hingga sangat berat. Dari penelitian ini didapatkan diagnosis penyakit anak yang paling dominan menyebabkan kecemasan dan depresi pada orang tua, yaitu diare, bronkopneumonia, dan kejang demam. Simpulan: Kondisi anak yang dirawat di Instalasi Gawat Darurat RSUP Prof. Dr. R. D. Kandou dapat menimbulkan stres psikologik berupa kecemasan dan depresi pada orang tua.
\end{abstract}

Kata kunci: gangguan mental emosional, kecemasan, depresi, orang tua 
Gangguan mental emosional adalah kondisi yang mengindikasikan perubahan psikologis pada seseorang. Hal ini dapat dialami oleh semua orang pada kondisi distres psikologis, namun tetapi dapat pulih seperti semula. Gangguan ini dapat berlanjut menjadi yang lebih serius bila tidak berhasil ditanggulangi. Gangguan mental emosional dapat berupa gejala depresi, gangguan psikosomatik dan ansietas. ${ }^{1}$

Kecemasan adalah suatu sinyal peringatan dari bahaya yang mengancam dan memungkinkan seseorang mengambil tindakan untuk mengatasi ancaman tersebut. Perasaan cemas paling umum ditandai rasa tidak nyaman, rasa takut yang tidak jelas, dan sering kali disertai dengan gejala otonomik. $^{2}$

Depresi merupakan gangguan mental yang ditandai dengan munculnya gejala penurunan mood, kehilangan minat terhadap sesuatu, perasaan bersalah, gangguan tidur atau nafsu makan, kehilangan energi dan penurunan konsentrasi. ${ }^{3}$

Menurut data World health organization (WHO) 2016 terdapat sekitar 35 juta orang mengalami gangguan depresi, 60 juta orang mengalami gangguan bipolar, 21 juta mengalami skizofrenia, serta 47,5 juta mengalami dimensia. ${ }^{4}$ Data Riskesdas 2013 menunjukan prevalensi gangguan mental emosional yang ditunjukan dengan gejala depresi dan kecemasan untuk usia 15 tahun keatas mencapai 14 juta orang atau 6 $\%$ dari jumlah penduduk Indonesia. ${ }^{1}$

National comorbidity study melaporkan bahwa satu dari empat orang mendapat diagnosis untuk satu kriteria gangguan kecemasan dengan prevalensi 1 tahun sebesar $77,7 \%$. Perempuan lebih cenderung memiliki gangguan kecemasan seumur hidupnya dengan prevalensi $30,5 \%$ dibandingkan laki-laki 19,2\%. ${ }^{5}$ Sama halnya dengan kecemasan, depresi juga lebih sering terjadi pada perempuan dengan prevalensi $5,1 \%$ dibandingkan laki-laki $3,6 \%$, dengan tingkat prevalensi bervariasi menurut usia, memuncak pada usia dewasa dan lebih tua lebih dari $7,5 \%$ pada perempuan berusia 55-74 tahun, dan lebih dari $5,5 \%$ pada laki-laki. ${ }^{6}$
Studi tentang kecemasan dan depresi pada ibu dari bayi yang dirawat di Neonatal Intensive Care Unit (NICU) mendapatkan dari 200 ibu bayi yang dirawat di NICU $25,5 \%$ menunjukan gejala klinis depresi, sedangkan gejala kecemasan derajat minimal $42,1 \%$, ringan $30,3 \%$, sedang $17,4 \%$, dan berat $10,3 \%$.

Studi lainnya pada orang tua anak dengan penyakit kronis, didapatkan tingkat kecemasan yang lebih tinggi pada orang tua anak dengan penyakit kronis dibandingkan dengan orang tua anak tanpa penyakit kronis. Ibu memiliki tingkat kecemasan $5,9 \%$ dan tingkat depresi $4,5 \%$ sedangkan pada ayah tingkat kecemasan $4,8 \%$ dan depresi $4,5 \%$. Pada penelitian ini telihat tingkat kecemasan dan depresi pada ibu lebih tinggi dibandingkan ayah. Sebagai konsekuensi dari beban ini, orang tua berisiko mengalami masalah psikososial. ${ }^{8-9}$

Pengalaman memiliki anak yang dirawat di rumah sakit karena penyakit atau cedera yang mengancam jiwa dapat menyebabkan reaksi psikologis yang mendalam untuk orang tua. Dalam situasi seperti itu, beberapa penelitian telah melaporkan reaksi stres traumatik akut yang secara klinis terjadi pada orang tua, yang melibatkan gejala depresi, kecemasan dan stres. Tidak mengherankan, reaksi psikologis orang tua ini hadir di sejumlah kelompok penyakit yang berbeda, seperti orang tua anak yang dirawat di Instalasi Gawat Darurat (IGD) dan orang tua anak yang dirawat di Pediatric Intensive Care Unit (PICU). ${ }^{10}$

Penelitian ini dilakukan berdasarkan latar belakang masalah di atas dan tingginya prevalensi gangguan mental emosional yang digambarkan dengan kecemasan dan depresi serta variasi penelitian-penelitian sebelumnya yang menyatakan tingginya tingkat kecemasan dan depresi pada orang tua dengan anak yang dirawat atau memiliki penyakit tertentu.

\section{METODE PENELITIAN}

Jenis penelitian ialah deskriptif kuantitatif dengan desain potong lintang 
dan menggunakan metode purposive sampling yaitu consecutive sampling. Penelitian ini dilakukan di Instalasi Gawat Darurat RSUP Prof. Dr. R. D. Kandou Manado pada bulan Oktober hingga November 2017.

Responden penelitian ialah orang tua yang anaknya dirawat di IGD RSUP Prof. Dr. R. D. Kandou Manado dengan kriteria inklusi yaitu orang tua dari anak yang dirawat di IGD selama $\leq 3$ hari dan orang tua kandung. Data penelitian ini diambil menggunakan kuesioner Self Reporting Qustionnaire (SRQ) dan Depression Anxiety Stress Scale (DASS). ${ }^{11}$

\section{HASIL PENELITIAN}

Berdasarkan penelitian kuantitatif yang dilakukan di IGD RSUP Prof. Dr. R. D. Kandou Manado periode bulan OktoberNovember 2017, didapatkan 72 orang tua yang anaknya dirawat sebagai responden yang telah memenuhi kriteria inklusi dan eksklusi penelitian ini. Data yang didapatkan diolah dan hasilnya ditampilkan dalam bentuk tabel.

Hasil penelitian ini mendapatkan usia orang tua yang paling dominan yaitu usia 26-35 tahun sebanyak 29 orang tua $(40,3 \%)$. Jenis kelamin responden orang tua yang diwawancarai paling banyak ialah perempuan yaitu ibu sebanyak 53 orang tua $(73,6 \%)$ dengan tingkat pendidikan dominan yaitu SMA sebanyak 35 orang tua $(48,6 \%)$. Sebagian besar orang tua pada penelitian ini telah memiliki pekerjaan yaitu sebanyak 41 orang tua $(56,9 \%)$ dan status perkawinan orang tua lengkap sebanyak 69 orang tua $(95,8 \%)$ dengan sebagian besar memiliki jumlah anak 1-2 yaitu sebanyak 49 orang tua $(68,1 \%)$. Pendapatan per-bulan orang tua sebagian besar yaitu <Rp.2.600.000 sebanyak 43 orang tua $(57,9 \%)$ (Tabel 1$)$.

Terdapat 54 orang tua (75\%) mengalami gangguan mental emosional dan 18 orang tua $(25 \%)$ yang tidak mengalami gangguan mental emosional (Tabel 2).

Hasil penelitian mendapatkan sebagian besar orang tua yang anaknya dirawat di IGD berada dalam kondisi normal, yaitu 23 orang tua $(31,9 \%)$ sedangkan orang tua yang mengalami kecemasan sangat berat, yaitu sebanyak 10 orang tua $(13,9 \%)$ (Tabel $3)$.

Tabel 1. Karakteristik responden (orang tua)

\begin{tabular}{|c|c|c|}
\hline \multirow{2}{*}{$\begin{array}{l}\text { Karakteristik } \\
\text { orang tua }\end{array}$} & \multirow{2}{*}{$\begin{array}{r}n \\
72\end{array}$} & \multirow{2}{*}{$\begin{array}{c}\% \\
100\end{array}$} \\
\hline & & \\
\hline \multicolumn{3}{|l|}{ Usia (tahun) } \\
\hline 17-25 tahun & 9 & 12,5 \\
\hline 26-35 tahun & 29 & 40,3 \\
\hline 36-45 tahun & 28 & 39,0 \\
\hline 46-55 tahun & 6 & 8,3 \\
\hline \multicolumn{3}{|l|}{ Jenis kelamin } \\
\hline Ayah & 19 & 26,4 \\
\hline Ibu & 53 & 73,6 \\
\hline \multicolumn{3}{|l|}{ Tingkat pendidikan } \\
\hline SD & 6 & 8,3 \\
\hline SMP & 8 & 11,1 \\
\hline SMA & 35 & 48,6 \\
\hline Perguruan Tinggi & 23 & 31,9 \\
\hline \multicolumn{3}{|l|}{ Pekerjaan } \\
\hline Bekerja & 41 & 56,9 \\
\hline Tidak bekerja & 31 & 43,1 \\
\hline \multicolumn{3}{|l|}{ Status perkawinan } \\
\hline Orang tua lengkap & 69 & 95,8 \\
\hline Orang tua tunggal & 3 & 4,2 \\
\hline \multicolumn{3}{|l|}{ Jumlah anak } \\
\hline $1-2$ & 49 & 68,1 \\
\hline$>2$ & 23 & 31,9 \\
\hline \multicolumn{3}{|l|}{$\begin{array}{l}\text { Pendapatan per- } \\
\text { bulan (rupiah) }\end{array}$} \\
\hline$<2.600 .000$ & 43 & 59,7 \\
\hline$>2.600 .000$ & 29 & 40,3 \\
\hline
\end{tabular}

Tabel 2. Gangguan mental emosional responden (orang tua)

\begin{tabular}{lcc}
\hline \multicolumn{1}{c}{$\begin{array}{c}\text { Gangguan mental } \\
\text { emosional }\end{array}$} & Frekuensi & $\mathbf{( \% )}$ \\
\hline Mengalami gangguan & 54 & 75,0 \\
Tidak mengalami & 18 & 25,0 \\
gangguan & & \\
Total & 72 & 100,0 \\
\hline
\end{tabular}

Sebagian besar orang tua yang anaknya dirawat di IGD berada dalam kondisi normal, yaitu sebanyak 54 orang tua (75\%). Tidak ada orang tua yang mengalami depresi berat dan hanya sebagian kecil 
orang tua yang mengalami depresi sangat berat, yaitu 3 orang tua $(4,2 \%)$ (Tabel 4$)$.

Tabel 3. Tingkat kecemasan responden (orang tua)

\begin{tabular}{ccc}
\hline $\begin{array}{c}\text { Tingkat } \\
\text { kecemasan }\end{array}$ & Frekuensi & $(\boldsymbol{\%})$ \\
\hline Normal & 23 & 31,9 \\
Ringan & 13 & 18,1 \\
Sedang & 19 & 26,4 \\
Berat & 7 & 9,7 \\
Sangat berat & 10 & 13,9 \\
Total & 72 & 100,0 \\
\hline
\end{tabular}

Pada distribusi diagnosis penyakit anak diambil diagnosis penyakit anak dari 54 orang tua yang megalami gangguan mental emosional kemudian dinilai tingkat kecemasan dan depresi yang dialami oleh orang tua tersebut (Tabel 5). Penyakit pada anak yang dirawat di IGD yang dominan menimbulkan kecemasan pada orang tua yaitu diare (13\%), bronkopneumonia $(9,3 \%)$, dan kejang demam (9,3\%). Penyakit pada anak yang dominan menimbulkan depresi pada orang tua yaitu diare $(3,7 \%)$ dan bronkopneumonia $(3,7 \%)$.

Tabel 4. Tingkat depresi responden (orang tua)

\begin{tabular}{ccc}
\hline Tingkat depresi & Frekuensi & $\mathbf{( \% )}$ \\
\hline Normal & 54 & 75,0 \\
Ringan & 11 & 15,3 \\
Sedang & 4 & 5,6 \\
Berat & 0 & 0 \\
Sangat berat & 3 & 4,1 \\
Total & 72 & 100,0 \\
\hline
\end{tabular}

Tabel 5. Distribusi diagnosis penyakit anak dengan tingkat kecemasan dan depresi

\begin{tabular}{ccccccccccccc}
\hline & \multicolumn{4}{c}{$\begin{array}{c}\text { Tingkat } \\
\text { Diagnosis }\end{array}$} & \multicolumn{4}{c}{$\begin{array}{c}\text { kecemasan } \\
\text { penyakit anak }\end{array}$} & $\begin{array}{c}\text { Normal } \\
\text { Kecemasan }\end{array}$ & Total & \multicolumn{3}{c}{ Tingkat depresi } & \multicolumn{2}{c}{ Total } \\
& $\mathrm{n}$ & $\%$ & $\mathrm{n}$ & $\%$ & $\mathrm{n}$ & $\%$ & $\mathrm{n}$ & $\%$ & $\mathrm{n}$ & $\%$ & $\mathrm{n}$ & $\%$ \\
\hline Bronkopneumonia & 3 & 5,6 & 5 & 9,3 & 8 & 14,8 & 6 & 11,1 & 2 & 3,7 & 8 & 14,8 \\
Kejang demam & 2 & 3,7 & 5 & 9,3 & 7 & 13,0 & 6 & 11,1 & 1 & 1,9 & 7 & 13,0 \\
Tonsilofaringitis & 0 & 0,0 & 3 & 5,6 & 3 & 5,6 & 2 & 3,7 & 1 & 1,9 & 3 & 5,6 \\
Suspek ASD & 1 & 1,9 & 1 & 1,9 & 2 & 3,7 & 1 & 1,9 & 1 & 1,9 & 2 & 3,7 \\
Suspek ToF & 0 & 0,0 & 1 & 1,9 & 1 & 1,9 & 0 & 0,0 & 1 & 1,9 & 1 & 1,9 \\
Suspek viral infection & 1 & 1,9 & 5 & 9,3 & 6 & 11,1 & 3 & 5,6 & 3 & 5,6 & 6 & 11,1 \\
Diare & 1 & 1,9 & 7 & 13,0 & 8 & 14,8 & 6 & 11,1 & 2 & 3,7 & 8 & 14,8 \\
Suspek anemia aplastik & 1 & 1,9 & 1 & 1,9 & 2 & 3,7 & 1 & 1,9 & 1 & 1,9 & 2 & 3,7 \\
DBD & 0 & 0,0 & 5 & 9,3 & 5 & 9,3 & 4 & 7,4 & 1 & 1,9 & 5 & 9,3 \\
Rinofaringitis & 0 & 0,0 & 2 & 3,7 & 2 & 3,7 & 2 & 3,7 & 0 & 0,0 & 2 & 3,7 \\
Ileus obstruksi & 2 & 3,7 & 0 & 0,0 & 2 & 3,7 & 2 & 3,7 & 0 & 0,0 & 2 & 3,7 \\
Suspek sindrom nefrotik & 0 & 0,0 & 4 & 7,4 & 4 & 7,4 & 1 & 1,9 & 3 & 5,6 & 4 & 7,4 \\
Glomerulonefritis akut & 0 & 0,0 & 1 & 1,9 & 1 & 1,9 & 1 & 1,9 & 0 & 0,0 & 1 & 1,9 \\
Hernia & 1 & 1,9 & 1 & 1,9 & 2 & 3,7 & 2 & 3,7 & 0 & 0,0 & 2 & 3,7 \\
Kolestasis & 1 & 1,9 & 0 & 0,0 & 1 & 1,9 & 1 & 1,9 & 0 & 0,0 & 1 & 1,9 \\
Total & 13 & 24,1 & 41 & 75,9 & 54 & 100,0 & 38 & 70,4 & 16 & 29,6 & 54 & 100,0 \\
\hline
\end{tabular}

\section{BAHASAN}

Pada penelitian ini dilakukan uji normalitas dengan cara Kolmogorov-
Smirnov. Dalam penelitian ini didapatkan nilai $P<0,05$ yang berarti data terdistribusi tidak normal. Hal ini dapat terjadi akibat 
jumlah sampel yang sedikit yaitu 72 responden, dan perbandingan antara case dan non case tidak seimbang sehingga tidak bermakna secara statistik. ${ }^{12}$

\section{Gangguan mental emosional}

Instrumen penelitian ini menggunakan kuesioner SRQ untuk mengetahui apakah orang tua yang anaknya dirawat di IGD mengalami gangguan mental emosional atau tidak. Dari hasil penelitian ini ditemukan sebanyak 54 orang tua $(75 \%)$ mengalami gangguan mental emosional, sedangkan yang tidak mengalami gangguan mental emosional sebanyak 18 orang tua (25\%). Kondisi ini menunjukkan bahwa orang tua yang anaknya dirawat di IGD berisiko mengalami gangguan mental emosional akibat kondisi anak yang dirawat. Orang tua cenderung akan menggunakan mekanisme koping untuk mengatasi kecemasannya. Namun, karena mekanisme koping tersebut berlangsung secara tidak disadari dapat menjadi respons maladaptif terhadap stres berupa peningkatan risiko mengalami gangguan mental emosional. $^{13}$

\section{Tingkat kecemasan}

Jumlah responden orang tua sebanyak 23 orang tua $(31,9 \%)$ tidak mengalami kecemasan/normal, 13 orang tua $(18,1 \%)$ mengalami kecemasan ringan, 19 orang tua (26,4\%) mengalami kecemasan sedang, 7 orang tua $(9,7 \%)$ mengalami kecemasan berat, dan sebanyak 3 orang tua $(4,2 \%)$ mengalami kecemasan sangat berat (Tabel 3). Penelitian serupa yang dilakukan Madianingsih $^{14}$ di IGD RSUD Wates Kulon Progo mendapatkan tingkat kecemasan yang lebih tinggi, yaitu sebanyak 26,8\% mengalami kecemasan berat. Penelitian yang dilakukan Ashrafizadeh et al. ${ }^{15}$ mendapatkan tingkat kecemasan tinggi terjadi pada orang tua yang anaknya menderita blood disease yaitu sebanyak $20,4 \%$ orang tua mengalami kecemasan berat.

\section{Tingkat depresi}

Sebanyak 54 orang tua $(75 \%)$ tidak mengalami depresi/ normal, 11 orang tua $(15,3 \%)$ mengalami depresi ringan, 4 orang tua $(5,6 \%)$ mengalami depresi sedang, dan 3 orang tua $(4,2 \%)$ mengalami depresi sangat berat (Tabel 4). Pada penelitian ini lebih banyak orang tua yang tidak mengalami depresi/normal dibandingkan dengan orang tua yang mengalami depresi. Hasil penelitian ini sejalan dengan penelitian Ashrafizadeh et al. ${ }^{15}$ yaitu pada orang tua anak dengan blood disease didapatkan sebagian besar orang tua tidak mengalami depresi (40\%). Hal ini didukung oleh Jafary et al. $^{16}$ yang mendapatkan sebagian besar orang tua yang menjadi responden tidak mengalami depresi/normal. Penelitian-penelitian ini menunjukkan bahwa tingkat depresi pada orang tua berbeda tergantung dari jenis penyakit yang dialami anaknya. Semakin parah penyakit anak maka semakin tinggi tingkat kecemasan dan depresi yang dialami orang tua. ${ }^{15-16}$

\section{Diagnosis penyakit}

Distribusi orang tua berdasarkan diagnosis penyakit anak mendapatkan 3 penyakit terbanyak yang menyebabkan orang tua mengalami kecemasan dan depresi pada penelitian ini, yaitu diare, bronkopneumonia, dan kejang demam. Hasil penelitian ini mendapatkan dari 8 orang tua yang anaknya didiagnosis dengan diare sebanyak 7 orang tua $(13,0 \%)$ mengalami kecemasan dan sebanyak 2 orang tua $(3,7 \%)$ mengalami depresi (Tabel 5).

Penelitian yang dilakukan Iswati et al. ${ }^{17}$ di puskesmas wilayah Kecamatan Semarang Timur menlaporkan dari 106 orang tua yang menjadi responden didapatkan sebanyak 79 orang tua $(74,5 \%)$ yang anaknya didiagnosis dengan diare mengalami kecemasan.

Penyakit diare sampai saat ini masih menjadi masalah kesehatan masyarakat. Pada tahun 2014 kasus penyakit diare di Provinsi Sulawesi Utara sebanyak 25,284 kasus. Pada tahun 2016 diperkirakan akan terjadi peningkatan jumlah kasus diare yaitu menjadi 65,127 kasus. Angka mortalitas yang tinggi karena penyakit diare yang 
semakin meningkat akan meningkatkan kecemasan orang tua pula. ${ }^{17-18}$

Hasil penelitian ini mendapatkan dari 8 orang tua yang anaknya didiagnosis dengan bronkopneumonia sebanyak 5 orang tua $(9,3 \%)$ yang mengalami kecemasan dan sebanyak 2 orang tua $(3,7 \%)$ yang mengalami depresi. Penelitian yang dilakukan Angkasa et al. ${ }^{19}$ di Kota Pekalongan mendapatkan sebagian besar responden tidak mengalami kecemasan. Hal ini terjadi karena orang tua mendapatkan dukungan yang baik dari keluarga. Ibu dari anak yang menderita bronkopneumonia membutuhkan dukungan keluarga dalam menghadapi penyakit tersebut karena penyakit ini membutuhkan pengobatan yang lama dan teratur. Dukungan keluarga merupakan unsur penting dalam membantu individu menyelesaikan masalah. ${ }^{13-19}$

Hasil penelitian ini mendapatkan bahwa 5 dari 7 orang tua $(9,3 \%)$ yang anaknya didiagnosis dengan kejang demam. Kejang demam merupakan keadaan yang paling dikhawatirkan para orang tua saat anaknya mengalami demam tinggi. Kekhawatiran tersebut disebabkan oleh rasa takut akan dampak yang terjadi akibat penyakit kejang demam yang tidak ditangani antara lain: kerusakan otak, retardasi mental, epilepsi, bahkan menyebabkan kematian. ${ }^{20}$

\section{Gambaran tingkat kecemasan dan depresi orang tua berdasarkan karakteristik orang tua}

Pada penelitian ini didapatkan distribusi orang tua yang paling banyak mengalami kecemasan ringan-sedang ialah yang berusia 26-35 tahun sebanyak 15 orang tua $(20,8 \%)$, sedangkan untuk orang tua yang mengalami kecemasan beratsangat berat paling banyak pada usia 36-45 tahun, yaitu 8 orang tua $(11,1 \%)$. Untuk depresi didapatkan orang tua yang berusia 36-45 tahun mengalami depresi ringansedang sebanyak 7 orang tua $(9,7 \%)$, sedangkan usia 46-55 tahun hanya 1 orang tua $(1,4 \%)$ yang mengalami depresi beratsangat berat. Hasil penelitian ini sejalan dengan Stuart ${ }^{13}$ yang menyatakan bahwa usia tua lebih rentan mengalami kecemasan dibandingkan usia muda. Gangguan kecemasan dapat terjadi pada semua usia namun lebih sering pada usia dewasa karena banyak masalah yang dihadapi. ${ }^{13-21}$ Shukrya et al. ${ }^{22}$ juga menyatakan bahwa tingkat depresi lebih tinggi terjadi pada orang tua yang berusia diatas 30 tahun.

Responden orang tua yang berpartisipasi pada penelitian ini umumnya ialah ibu dibandingkan dengan ayah. Ibu yang mengalami kecemasan ringan-sedang sebanyak 26 ibu $(36,1 \%)$ sedangkan ayah yang mengalami kecemasan berat-sangat berat sebanyak 8 ayah $(11,1 \%)$. Untuk depresi didapatkan ibu yang mengalami depresi ringan-sedang sebanyak $10 \mathrm{ibu}$ $(13,9 \%)$ sedangkan ayah yang mengalami depresi ringan-sedang sebanyak 5 ayah $(6,9 \%)$. Hal ini sangat sesuai dengan teori Videbeck (2008) yang menyatakan bahwa laki-laki dan perempuan mempunyai perbedaan tingkat kecemasan, yaitu perempuan lebih mudah tersingung, sangat peka, dan menonjolkan perasaanya sedangkan laki-laki lebih rasional dan tidak menonjolkan perasaanya. ${ }^{20}$

Pada penelitian ini orang tua yang memiliki tingkat pendidikan SMA sebagian besar mengalami kecemasan ringansedang, yaitu sebanyak 16 orang tua $(22,2 \%)$ sedangkan yang berpendidikan SD hanya 3 orang tua $(4,2 \%)$ mengalami kecemasan ringan-sedang. Pada penelitian ini didapatkan data orang tua yang berpendidikan SMA sebanyak 6 orang tua $(8,3 \%)$ mengalami depresi ringan-sedang sedangkan orang tua yang jenjang pendidikanya sampai perguruan tinggi tidak ada yang mengalami depresi berat-sangat berat. Penelitian ini sejalan dengan teori Gass dan Curiel (2011) yaitu semakin tinggi tingkat pendidikan sesorang semakin tinggi pula tingkat kecemasan orang tersebut. Orang tua dengan tingkat pendidikan yang tinggi, secara tidak langsung ingin mengetahui lebih banyak mengenai penyakit yang diderita anaknya, dengan demikian semakin banyak informasi yang diperoleh semakin meningkatkan tingkat kecemasan dan depresi yang dialaminya. ${ }^{23}$ 
Berdasarkan hasil penelitian didapatkan status perkawinan orang tua lengkap sebanyak 32 orang tua $(44,4 \%)$ mengalami kecemasan ringan-sedang sedangkan status perkawinan orang tua tunggal sebanyak 2 orang tua $(2,8 \%)$ mengalami kecemasan berat-sangat berat. Status perkawinan orang tua lengkap yang mengalami depresi ringan-sedang sebanyak 13 orang tua $(18,1 \%)$ sedangkan orang tua tunggal yang mengalami depresi ringan-sedang sebanyak 2 orang tua $(2,8 \%)$. Kullu et al. dalam penelitiannya menyatakan bahwa orang tua yang memiliki anak cacat dan telah bercerai lebih berisiko mengalami kecemasan dan depresi karena mereka harus merawat anak cacat dan melakukan semua aktivitas yang perlu dilakukan dalam kehidupan sehari-hari yang meningkatkan kecemasan dan depresi pada orang tua tunggal. ${ }^{24}$

Pada penelitian ini didapatkan data orang tua yang memiliki 1-2 anak sebanyak 25 orang tua $(34,7 \%)$ mengalami kecemasan ringan-sedang sedangkan orang tua yang memiliki $>2$ anak mengalami depresi ringan-sedang sebanyak 7 orang tua $(9,7 \%)$. Shukrya et al. ${ }^{22}$ mendapatkan tingkat depresi lebih tinggi pada orang tua yang memiliki lebih dari 4 anak, yaitu sebanyak 38,6\% mengalami depresi berat. Tingkat depresi lebih tinggi terjadi pada orang tua yang memiliki anak lebih dari 4 ini dikarenakan orang tua harus menyeibangkan antara mengurus anak yang sakit dan mengurus anak-anak yang lainnya. ${ }^{22}$

Pada penelitian ini berdasarkan status pekerjaan, tidak bekerja sebanyak 17 orang tua $(23,6 \%)$ mengalami kecemasan ringansedang dan orang tua yang memiliki pendapatan $<2.600 .000$ sebanyak 20 orang tua $(27,8 \%)$ mengalami kecemasan ringansedang. Stuart ${ }^{13}$ berpendapat bahwa kecemasan dapat muncul karena konflik peran. Ibu yang memiliki peran ganda, bekerja mencari nafkah, mengurus rumah tangga dan harus merawat anak yang sakit akan menimbulkan kecemasan karena tidak mampu melakukan peran dengan baik. Berbagai kegiatan tersebut meningkatkan aktifitas ibu dan menimbulkan kelelahan yang pada akhirnya menstimulus kecemasan dan depresi. ${ }^{13}$

\section{SIMPULAN}

Sebagian besar orang tua yang anaknya dirawat di IGD mengalami gangguan mental emosional, kecemasan sedang, dan depresi ringan.

Diagnosis penyakit anak yang dirawat di IGD yang dominan menyebabkan orang tua mengalami kecemasan dan depresi, yaitu diare, bronkopneumonia dan kejang demam.

\section{SARAN}

Disarankan kepada Institusi untuk memperhatikan kondisi pasien dan keluarga bukan hanya kondisi fisik pasien, tapi juga meningkatkan kualitas pelayanan, kenyamanan ruangan dan kebersihan ruangan agar pasien dan keluarga pasien bisa merasa nyaman dan mengurangi faktor yang dapat memicu kecemasan dan depresi.

Disarankan kepada orang tua untuk menjaga kesehatan anak dan keluarga, sehingga memiliki kualitas hidup yang baik dan segera meminta bantuan tenaga kesehatan terdekat bila salah satu anggota keluarga sakit.

Penelitian lanjut diharapkan dapat mengaitkan lama perawatan dengan tingkat kecemasan dan depresi. Disarankan juga untuk melakukan penelitian pada orang tua anak yang di rawat di PICU/ NICU karena kemungkinan tingkat kecemasan dan depresi yang dialami orang tua lebih tinggi dibandingkan dengan yang di IGD.

\section{DAFTAR PUSTAKA}

1. Riset Kesehatan Dasar (Riskesdas). (2013). Badan Penelitian dan Pengembangan Kesehatan Kementerian RI tahun 2013. [cited 2017 Sep 10] Available from: http://www.depkes.go.id/resources/dow nload/general/Hasil\%20Riskesdas\%20 2013.pdf

2. Sadock BJ, Sadock VA, Ruiz P. Synopsis of Psychiatry (11 ed).New York: Wolters Kluwer, 2015; p. 388-9.

3. World Health Organization. Depression. 2017 Feb [cited 2017 Aug 08]. Available from: 
http://www.who.int/mental_health/man agement/depression/en/

4. World Health Organization. Mental Disorder. 2017 Feb [cited 2017 Sep 18]. Available from: http://www.who.int/mediacentre/factsh eets/fs396/en/

5. Daniel SP. Anxiety disorders: Introduction and overview. In :Sadock. BJ, Sadock. VA, Ruiz P, editors. Comprehensive Textbook of Psychiatry (9th ed). Philaddelphia: William \& Wilkins, 2009; p.1840.

6. World Health Organization. Depression and Other Common Mental Disorder. 2017 [cited 2017 Aug 09]. Available from: http://apps.who.int/iris/bitstream/10665 /254610/1/WHO-MSD-MER-2017.2eng.pdf.

7. Segre LS, McCabe JE, Chuffo-Siewert R, O'Hara MW. Depression and anxiety symptoms in mothers of newborns hospitalized on the neonatal intensive care unit. Nurs Res. 2014;63(5):325-6.

8. Haverman OL, Limperg PF, Dijk-Lokkart EM, Stam HM, Grootenhuis MA. Anxiety and depression in mothers and fathers of a chronically ill child. Matern Child Health J. 2014;1:10-6.

9. Hatzmann J, Heymans HS, Carbonell A, van Praag BM, Grootenhuis MA. Hidden consequences of success in pediatrics: Parental health-related quality of life results from the Care Project. Pediatrics. 2008;122(5):1030 38.

10. Muscara F, McCarthy MC, Woolf C, Heasps SJC, Burke K, Anderson VA. Early psychological reactions in parents of children with a life threatening illness within a pediatric hospital setting. Eur Psychiatry. 2015;7:1-7.

11. Sudigdo S, Sofyan I. Dasar-dasar Metodologi Penelitian Klinis (5th ed). Jakarta: Sagung Seto, 2014; p. 376-77, 516.

12. Sunyoto D, Setiawan A. Buku Ajar: Statistik Kesehatan Parametrik, Non Parametrik, Validitas, dan Reliabilitas. Yogyakarta: Nuha Medika, 2013.

13. Stuart GW. Buku Saku Keperawatan Jiwa (5th ed). Jakarta: EGC, 2006; p. 140-5.

14. Madianingsih. A. Gambaran kecemasan keluarga pasien di Instalasi Gawat Darurat (IGD)RSUD Wates Kulon
Progo [Skripsi]. Yogyakarta: STIKES Jendral Achmad Yani; 2017.

15. Ashrafizadeh $H$, Adine $M$, Bazar S, Darvishi M. Depression and anxiety among parents of children with blood disease in Ahvaz, South West of Iran. International Journal of Pediatrics. 2016;4:2193-202.

16. Jafary MH, Vakilian R, Rezaei K, Zand K, Tajik K. Survey of levels of anxiety and depression in parents of children with chronik illnes. IJPN. 2014;1(4):4553.

17. Iswati I, Naviati E. Gambaran tingkat kecemasan ibu saat balita diare di Puskesmas Wilayah Kecamatan Semarang Timur. Jurnal Departemen Keperawatan. Universitas Diponegoro. 2017;1-8.

18. Dinas Kesehatan Provinsi Sulawesi Utara. Profil Kesehatan Provinsi Sulawesi Utara 2015. Manado. 2016

19. Angkasa MP, Isrofah, Inayah M, Dewi I. Hubungan dukungan keluarga dengan kecemasan ibu dari anak yang menderita bronkopneumonia di BKPM Kota Pekalongan. Jurnal LITBANG Kota Pekalongan. 2016;10:50-9.

20. Kustiawan. R, Anshori. FF. Gambaran tingkat kecemasan orang tua terhadap hospitalisasi anak dengan kejang demam di ruang anak bawah RSUD dr. Soekarjo Kota Tasikmalaya. Jurnal Kesehatan Bukit Tunas Husada. 2015;13(1):148-54.

21. Muscara F, McCarthy MC, Woolf C, Heasps SJC, Burke K, Anderson VA. Early psychological reactions in parents of children with a life threatening illness within a pediatric hospital setting. European Psychiatry. 2015;7:17.

22. Shukrya KM, Jasim A, Akell W, Sabah A. Prevalence and levels of depression among parents of children with cencer in Basrah, Iraq. SQU Medical Journal. 2016;16(3):329-34.

23. Gass SC, Curiel ER. Test anxiety in relation to measure of cognitive and intellectual functioning. Arch Clin Neuropsychol. 2011;26:396-404.

24. Rukeye A. An evaluation of anxiety in parents with disabled children and their coping strategies. IJCS. 2017;10(1): 342-53. 